\title{
SOUTH AFRICAN LEPIDOPTERA, 4
}

Three new Heterocera from the Kruger National Park

\author{
by \\ LAJOS VÁRI, D.Sc., \\ Transvaal Museum, Pretoria.
}

In a previous paper (Vári, 1962) it was stated that many more interesting and new species would be found in the National Parks of South Africa. These new species are not only among the Microlepidoptera, but also among the larger species of Heterocera, as the descriptions of the following new species show. The first species belongs to the Sphingidae, the second to a genus of the Arctiidae from Madagascar and the third to the Noctuidae. These discoveries are highly interesting, since new species of their size are certainly exceptional in South Africa nowadays.

The first specimen of the new sphingid collected by A. J. T. Janse in 1904 was not recognized as a new species, but considered to be the male of Polyptychus numosae (Wllgr.) (Swierstra, 1911); the specimen was later placed under $P$. fulgurans R. and J. in the museum's collection, where it was detected while the author was identifying a second specimen recently collected by him in the Kruger National Park. The third specimen is also collected in the same area. Although the new species does closely resemble these two congeners, it can, however, readily be identified.

The new arctiid species is most probably related to the Madagascan genus Axiopoeniella Strand, 1909 and is described in it with some reservation. Comparatively few species occur both in Madagascar and Southern Africa and therefore the occurrence of Grammodes exclusiva Pagenst. which is a Madagascan species and hitherto unknown from the African continent is very interesting. Surprisingly this species has only recently been collected in the Kruger National Park but at other localities in Southern and Central Africa also at earlier dates.

All types are in the collection of the Transvaal Museum, Pretoria, and one paratype of Polyptychus jansei and Axiopoeniella octocentra in the collection of the British Museum (Natural History), London. 

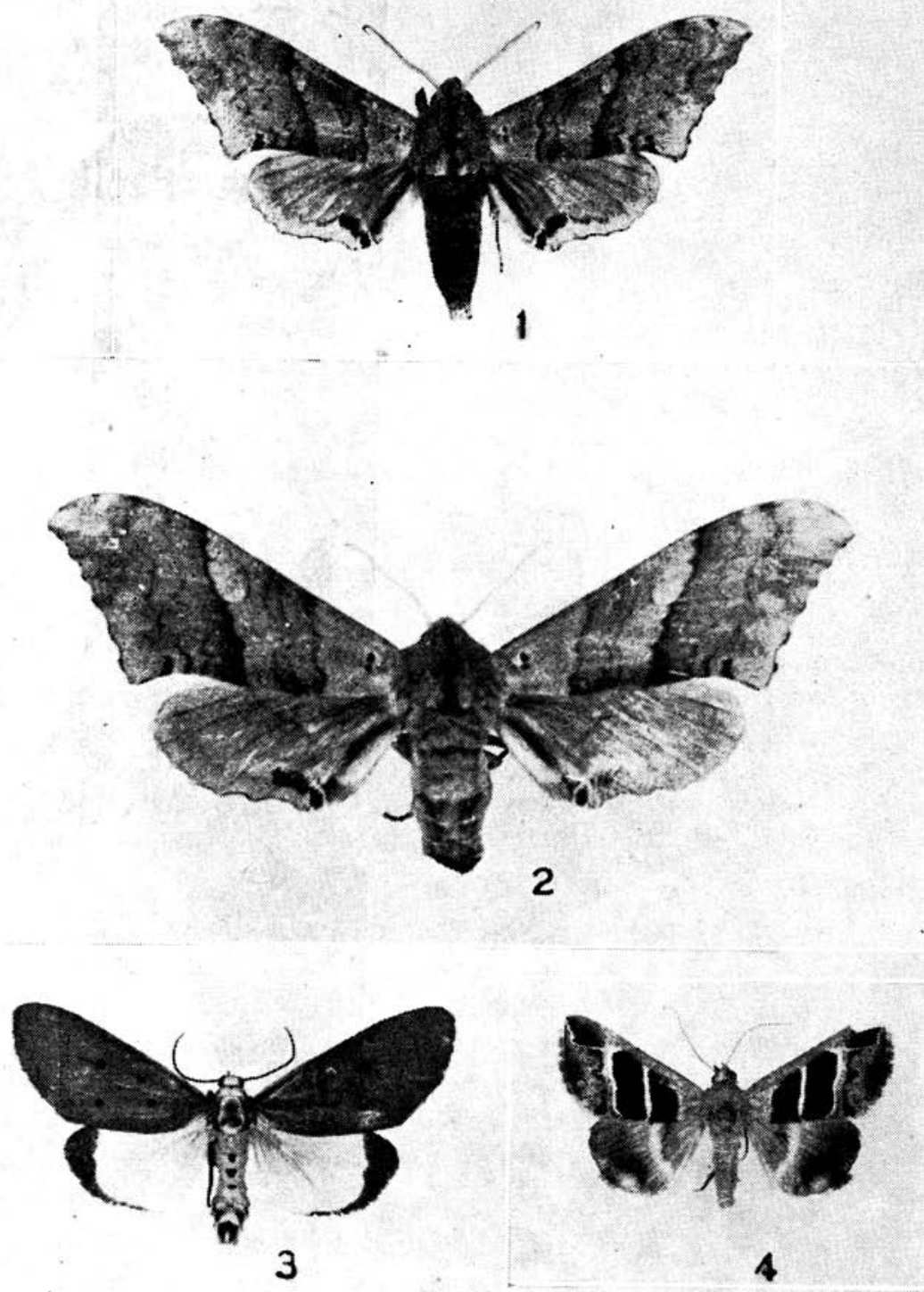

Photo: Vári.

Figs. 1 and 2: Polyptychus jansei spec.nov., 1. $\sigma^{x}$-holotype, 2. O-allotype; fig. 3. Axiopoeniella octocentra spec.nov., $\sigma^{\prime}$-holotype; fig. 4. Grammodes exclusiva Pagenst. 


\title{
Family SPHINGIDAE
}

\section{Polyptychus jansei spec.nov.}

\author{
Plate 1:1 and 2; textfig. 1
}

Polyptychus numosae (WIlgr.) sensu Swierstra, 1911, Ann. Transv. Mus. 1:226, pl. 35:2.

$\sigma^{*}$ and,$+ 59-69 \mathrm{~mm}$. Head and antennae greyish, palpi and a narrow edge in front of eyes reddish-brown; antennae grooved, well ciliated, in female less strongly grooved and cilia shorter; proboscis short and weakly developed. Abdomen grey with first two segments mixed with pale reddishbrown, thorax greyish above, with a narrow, reddish-brown midline, underside entirely reddish-brown. Legs greyish above, at underside and all coxae reddish-brown; middle tibiae dark fuscous with a round, whitish patch on outer side at base las in $P$. numosae and $P$. fulgurans); hind tibiae rather whitish on outer side. Forewings grey with a faint bluish sheen, slightly darker just beyond middle; two black subbasal dołs, a slightly undulate line at $\frac{1}{4}$ of wing at almost right angles to hindmargin, at $\frac{1}{3}$ two such lines a little irregular, slightly slanting, discal line just beyond $\frac{1}{2}$, well marked, finely and irregularly scalloped, outwardly bordered with dark fuscous, the small teeih pointing towards base, costal half of discal line faintly convex, other half feebly concave and a little less slanting than in numosae and fulgurans; in apical area three more or less parallel, undulate lines, towards costa a little stronger, third line with black scales at inner margin before tornus; termen undulate, cilia fuscous, dark fuscous at tip of veins; underside dark pinkish in basal half, gradually becoming greyish towards termen, a postmedian and subterminal reddish-brown, fine line, curved near costa. Hindwings reddish, gradually paler towards margin, hindmargin greyish, anal markings almost black, narrow, shaped as in fulgurans, edge of wing slightly undulate, cilia fuscous at base, whitish at apex; underside yellowish-grey, a median and postmedian sinuate line, median one strongest, the area between them slightly darker, anal markings faintly indicated.

$\sigma^{7}$-Genitalia (fig. 1): Tegumen sclerotized, simple; uncus strongly sclerotized, curved and pointed; gnathos arms separate, strongly curved and long-pointed; valvae subquadrangular, cuculus rounded, rather weakly sclerotized, sacculus heavily sclerotized, basal half with rounded projection, set with a few fine bristles, apex bluntly pointed; aedoeagus rather short, thickened in middle, apex truncate, coecum short, cylindrical, vesica with two very small cornuti; juxta triangular, well sclerotized; vinculum narrow, saccus very short. Genitalia slide no. G 7997, paratype.

Remarks: Mr. Swierstra (1911) described the first specimen of this species as being the until then unknown male of $P$. numosae (W Ilgr.) and illustrated his paper with a fine colour drawing by Janse.

The species is very close to P. fulgurans R. and J., but differs from 


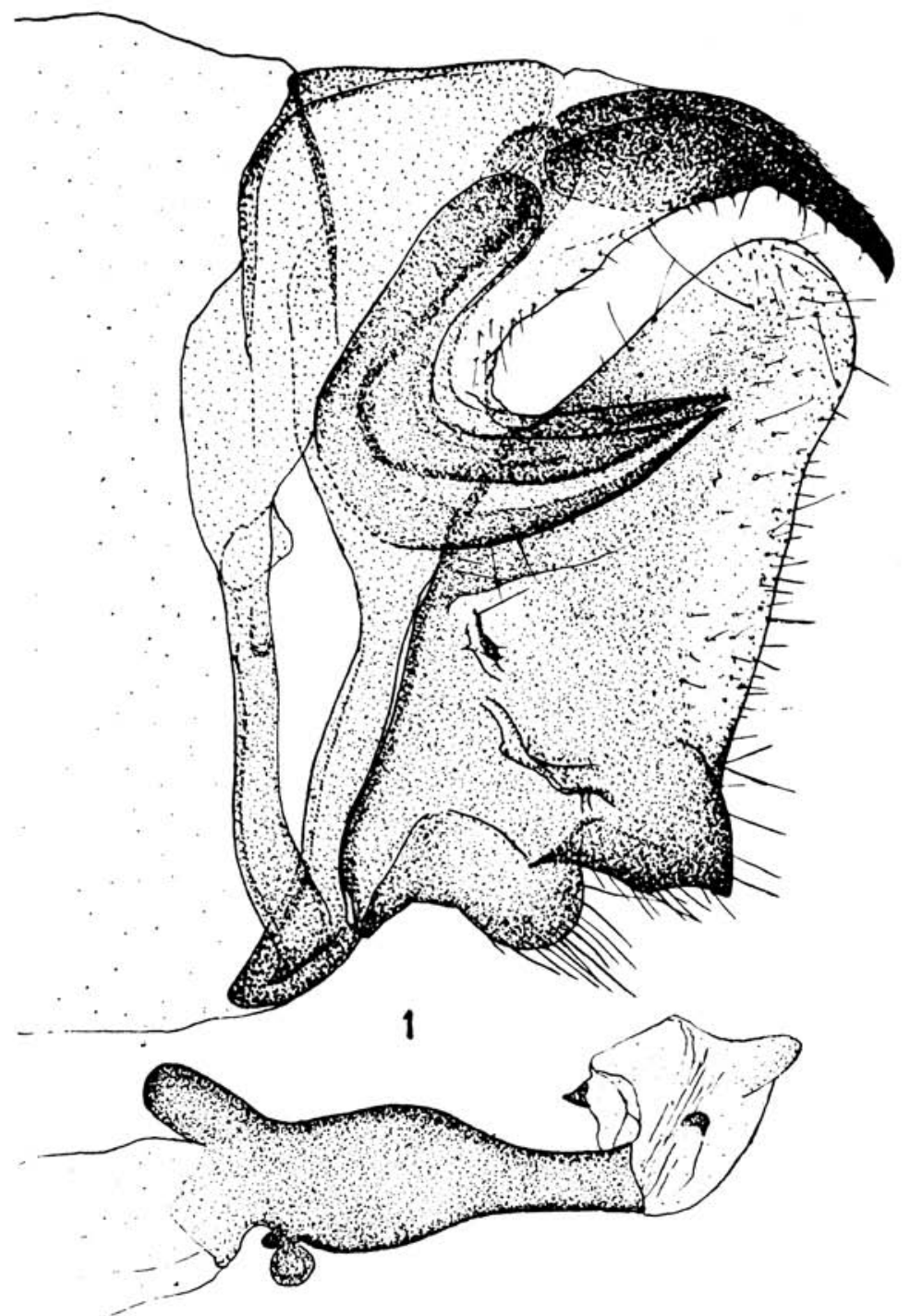

Fig. 1: Polyptychus jansei spec.nov., $\sigma^{x}$-genitalia, lateral. 
it by the discal line which is finely scalloped and slightly more upright. The colour of the forewings is a bluish-grey instead of a pinkish-grey as in fulgurans and the hindwings are a little more reddish.

Distribution: Warmberg (Pietersburg Distr., Tvl.), 7.I.1904 (A. J. T. Janse), $\sigma^{3}$-holotype; Pafuri (K.N.P., Tvl.), February 1961 (H. Mockford), q-allotype; Punda Milia (K.N.P., Tvl.), 21-23.XI.1961 (Vári and Rorke), one $0^{3}$-paratype, and Limburg (Potgietersrus Distr., Tvl.), 12.XII.1963 (L. Vári), three $\sigma^{\prime}$-paratypes.

\section{Family ARCTIIDAE}

\section{Axiopoeniella octocentra spec.nov.}

Plate 1:3; textfigs. 2 and 3

$\sigma^{7}, 39-40 \mathrm{~mm}$. Head chrome-yellow, antennae blackish fuscous, finely ciliated; palpi chrome-yellow, ihird segment dark fuscous; proboscis developed. Abdomen and thorax chrome-yellow, segments 2-7 with a black dot dorsally at anterior edge, and also a black dot laterally, the dots becoming gradually larger and on segment 8 almost joining dorsally, underside of segments 3-8 black with posterior edge yellow; thorax above with two lateral black spots near hindmargin. Legs dark fuscous, coxae and femora mixed with chrome-yellow, hind tibiae almost entirely yellow. Forewings uniformly dark fuscous, four black dots placed in a subquadrangle, basal pair a little closer together than discal pair; underside dark fuscous, in basal third mixed with yellow. Hindwings chrome-yellow, apical margin broadly blackish fuscous, gradually narrowing towards anal angle, cilia blackish fuscous from apex to anal angle, yellow along inner margin; underside as above.

Wing venation (fig. 2): Forewing subtriangular, termen oblique, vein 2 from ${ }^{4} / 5$ of lower median, 3 from angle, 3,4 and 5 at equal distances, 6 from near upper angle, 7,8 and 9 stalked from upper angle, 7 from stalk of 8 and 9,10 from ${ }^{6} \%$ of upper median, connected with stalk of 8 and 9 beyond 7 by a short bar thus forming an elongate areole, 11 from $2 / 3$ of upper median; hindwing semicircular, costa straight, vein 2 from $2 / 3$ of lower median, 3 from angle, 4 slightly nearer to 3 than to 5,6 and 7 connate from upper angle, 8 anastomosing from base with almost half of upper median.

$0^{2}$-Genitalia (fig. 3): Tegumen very narrow, uncus well developed, divided into two oval lobes, well sclerotized; no gnathos; valvae large, oval, outer side with a very fine honeycomb-like network and heavy core. mata, cuculus rounded, finely haired; sacculus strongly sclerotized, with a long, slender and sharp-pointed processus and a short tooth, a small ampulla above sacculus; aedoeagus very slender, almost straight, apex truncate, coecum long and narrow, vesica with one long and very slender cornutus, set with a few fine, slender teeth distally; vinculum moderate, 

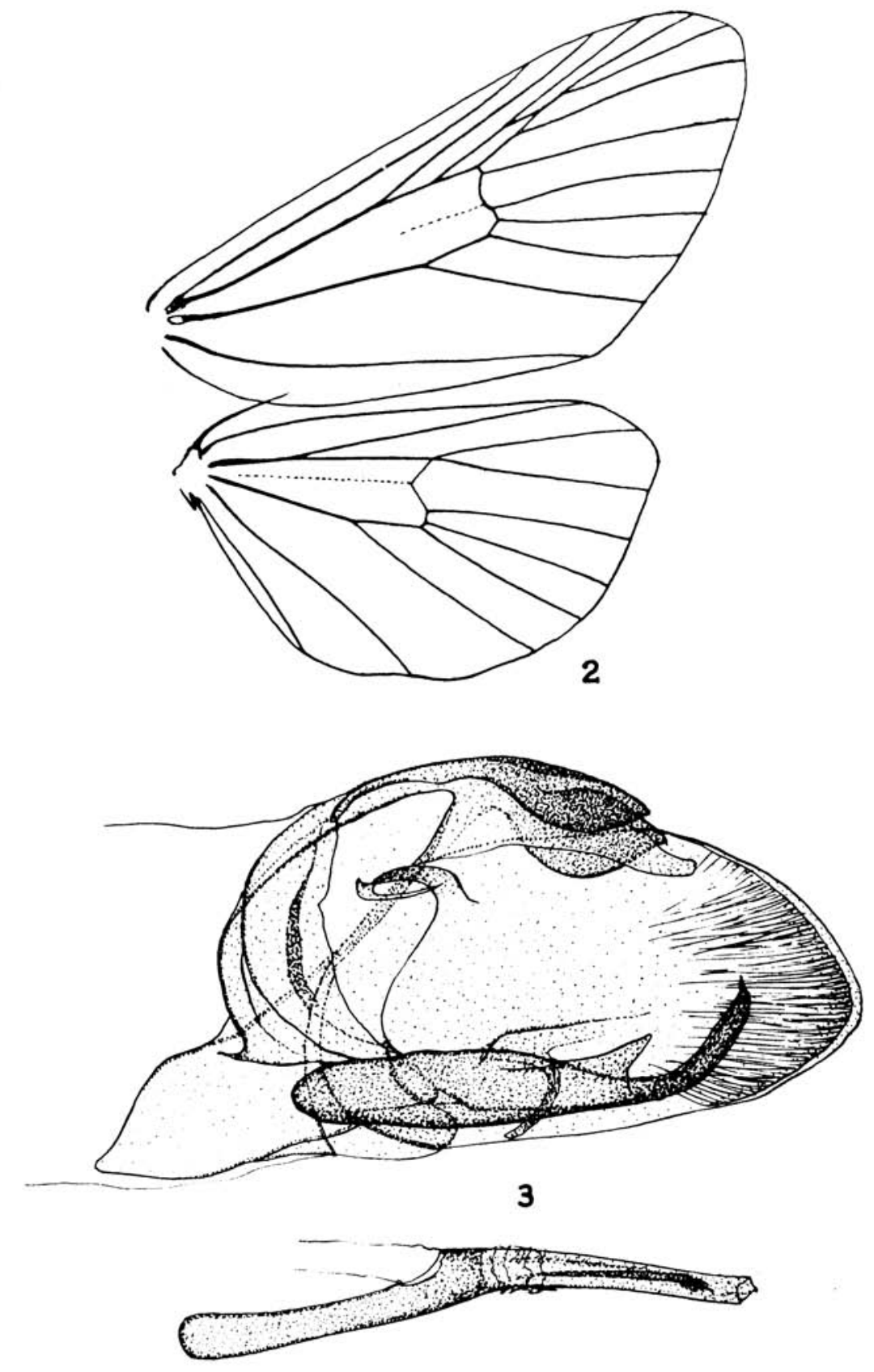

Figs. 2 and 3. Axiopoeniella octocentra spec.nov.,

fig. 2. wing venation; fig. 3. $\sigma^{x}$-genitalia, lateral. 
saccus bluntly pointed. Genitalia slide no. G 7998, paratype.

Remarks: This species is easily recognized by the eight black dots in centre of forewings and the yellow abdomen and hindwings.

Distribution: Punda Milia (K.N.P., Tvl.), 21-23.XI.1961 (Vári and Rorke), $\hat{o}$-holotype and two $\delta$-paratypes; Lundi River Bridge (Chibi Dist., S.Rhod.), 20.II.1954 (H. Cookson), one ô-paratype; idem, 2-5.III.1964 (Vári and Van Son), seven ô-paratypes, and idem, November 1950 (H. B. Kettlewell), one $\hat{\delta}$-paratype in collection British Museum (Nat. Hist.).

\section{Family NOCTUIDAE \\ Grammodes exclusiva Pagenst.}

Plate 1:4; textfigs. 4 and 5

Pagenstecher, 1907, Reise in Ostafrika 2:121, pl. 6:19.

An interesting species that possibly rather recently enlarged its area of distribution. Pagenstecher described the species without, however, studying the genitalia. The species is externally very similar to $G$. stolida Cram., but the structure of the genitalia is quite different and is as follows:

$\sigma^{\top}$-Genitalia (fig. 4): Tegumen moderate, uncus very strong, slightly curved, pointed; no gnathos; valvae subtriangular, on outer side with strong coremata at base, processus basalis very narrow and pointed, costa strongly curved, ampulla strongly sclerotized, pointed, cuculus tapering, long-pointed, slightly curved inwards, sacculus well sclerotized, long, with short, pointed processus; aedoeagus strong, apex truncate, coecum short, slightly upturned, vesica without cornutus; juxta membranous; vinculum moderate, saccus bluntly pointed. Genitalia slide no. G7958.

o-Genitalia (fig. 5): Papillae anales subtriangular, moderate, longhaired, apophyses very narrow, slightly sinuate; antapophyses very narrow, about half as long as apophyses; ostium bursae narrow, tranversally situated, lamella postvaginalis flat, lamella antevaginalis strongly sclerotized, bluntly pointed, projecting posteriorly; antrum short and well sclerotized, strongly curved, corpus bursae moderate, set with very fine and short setae near antrum, with very fine and short bristles on remaining part, no signum. Genitalia slide no. G 7957.

Remarks: Although G. exclusiva is closely allied to G. stolida which is a very common and widespread species in Africa, it can readily be distinguished from it by the following: the transverse, whitish median line is almost straight with no projecting tooth in middle; the whitish median fascia of hindwing is strongly suffused.

Distribution: Malelane (K.N.P., Tvl.), 3-5.XII.1963 (L. Vári); Satara lidem), 27.III.1952 (Janse and Vári); Letaba Camp lidem), 7-8.XII.1963 (L. Vári); Shingwidzi (idem), 19-20.XI.1961 (Vári and Rorke); Punda Milia 

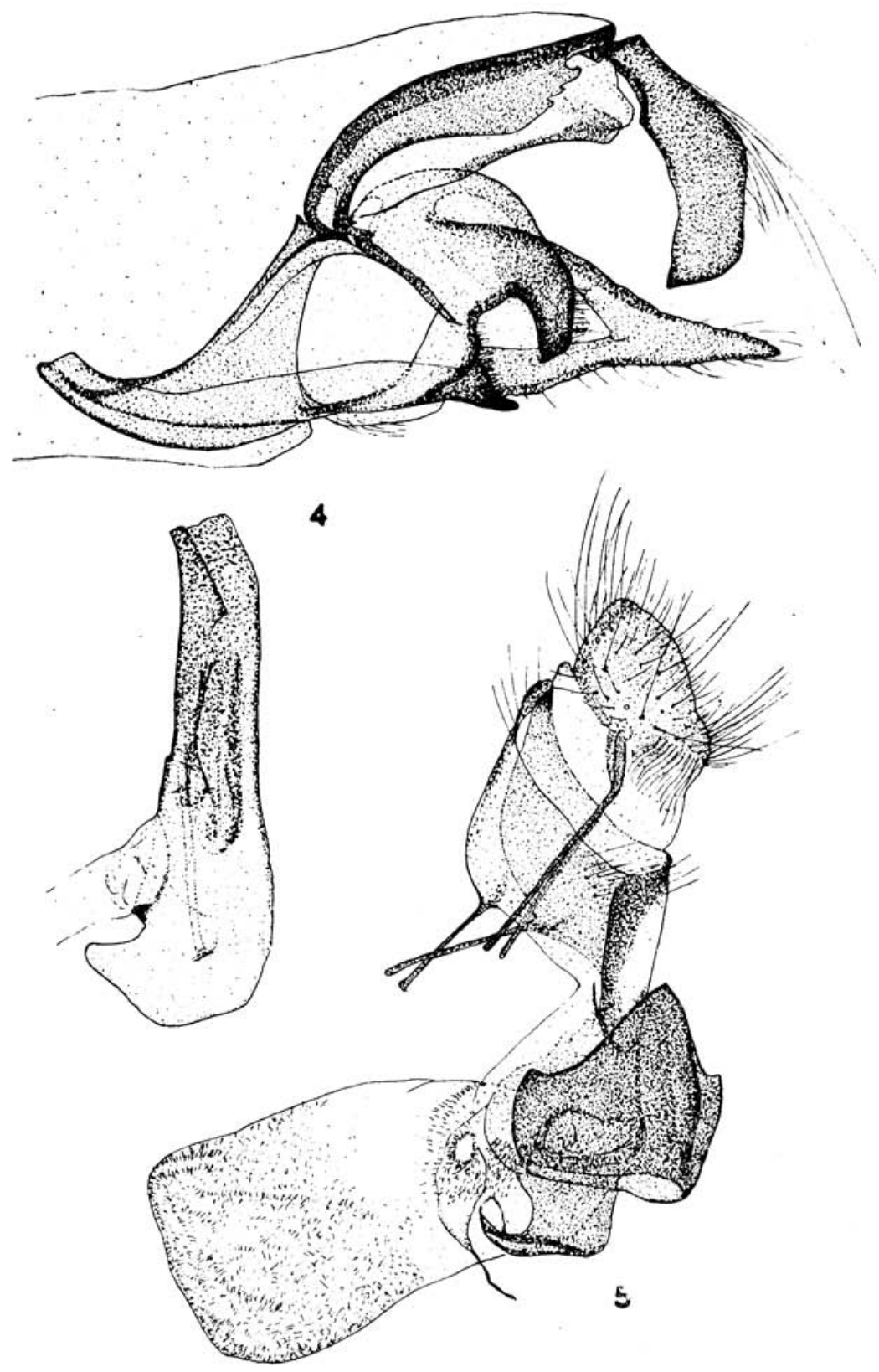

Figs. 4 and 5. Grammodes exclusiva Pagenst., fig. 4. $\sigma^{\top}$-genitalia, lateral; fig. 5. O-genitalia. 
lidem), 9-11.XII.1963 (L. Vári); Malta Forest (Pietersburg Distr., Tvl.), Febr. 1928 (G. van Son); Limburg (Potgietersrus Distr., Tvl.), 12.XII.1963 (L. Vári); Basutoland Border, 30 miles from Bethlehem (O.F.S.), 20.X.1950 (G. C. Clark); Resolution (Albany Dist., C.P.), 23.IV.1928 (A. Walton); Lourenço Marques (Moçambique), February 1954 (A. J. Barbosa) and Fort Victoria (Victoria Distr., S.Rhod.), 21.XI.1948 (J. Omer-Cooper), all in collection Transvaal Museum. Haenertsburg (Pietersburg Distr., Tvl.), 26.III.1922 (R. Stevenson); Weenen (Natal), February and September-October 1925, October, November and December 1926 (H. P. Thomasset); Natal National Park (Natal), March 1922 (J. Ogilvie); Chiromo (Nyasaland), 5.IV.1899 (E. M. de Jersey); Mount Mlanje (idem), 26.II.1913 (S. A. Neave); Mlanje Plateau (idem), 13.III.1913 (S. A. Neave); Machakos (Kenya), 14.XII.1898 (R. Crawshay); Voi (idem), 1.I.1913 (C. Montague Smyth) and Lodwar (Turkana Province, Kenya), 5.IV and 1.V.1934, all in collection British Museus (Nat. Hist.).

\section{ACKNOWLEDGEMENT}

The author wishes to express his sincere appreciation to Mr. D. S. Fletcher of the British Museum (Natural History), London, for his valuable assistance in identifying the new arctiid species described in this paper.

\section{REFERENCES}

Swierstra, C. J., 1911. Description of the male of Polyptychus numosae (Wligr.). Ann. Transv. Mus. 1:266, pl. 35:2.

Vári, L., 1962. South African Lepidoptera, 2. Descriptions of new species of Hypeninae from the Kruger National Park (Noctuidae). Koedoe 5:162-7. 